\title{
DINAMIKA PELAKSANAAN KURIKULUM 2013 PADA TINGKAT SEKOLAH MENENGAH PERTAMA DI KOTA SEMARANG
}

\author{
Margi Wahono dan Novia Wahyu Wardhani \\ Program Studi PPKn Universitas Negeri Semarang \\ margi85@mail.unnes.c.id
}

\begin{abstract}
Abstrak
The purpose of this study was to examine the implementation of the curriculum PPKn 2013 for Junior High School in targeted schools. In details, this research was aimed at (1) describing the influence of curricula across time; (2) describing the dynamics of implementation and its impact on the teachers' understanding; (3) describing the level of teachers' understanding on planning, implementing and evaluating based on curriculum 2013 guidance; and (4) stating a recommendation for curriculum policy makers in future. It was descriptive research. The methods for collecting data were questionnaire, interview, and observation. The results indicated that the teacher understood how to implement the curriculum, especially in teaching PPKn. PPKn teacher was able to plan, conduct, and evaluate of teaching PPKn authentically.
\end{abstract}

Keywords: curriculum 13, PPKn, SMP

\section{PENDAHULUAN}

Pelaksanaan pembelajaran pada Pendidikan Dasar dan Menengah (untuk pelaksanaan Kurikulum 2013) telah diatur melalui Peraturan Menteri Pendidikan dan Kebudayaan Nomor 103 Tahun 2014 beserta lampirannya (Pedoman Pelaksanaan Pembelajaran). Dalam lampiran Peraturan Menteri tersebut, dinyatakan tentang konsep dasar mengenai proses pembelajaran yaitu bahwa peserta didik dipandang sebagai subjek yang memiliki kemampuan secara aktif mencari, mengolah, mengkonstruksi, dan menggunakan pengetahuan. Sesuai dengan pandangan tersebut, pembelajaran hendaknya berkaitan dengan kesempatan yang diberikan kepada siswa untuk mengkonstruksi pengetahuan yang diperoleh dari proses kognitif. Selanjutnya, agar benarbenar memahami dan dapat menerapkan pengetahuan, maka siswa perlu didukung untuk dapat memecahkan masalah, menemukan segala sesuatu untuk dirinya, dan berupaya keras mewujudkan ide-ide.
Guru PPKn menghadapi masalah dalam pencapaian standar kelulusan diantaranya pertama, guru merasa belum memahami secara utuh pengembangan dimensi sikap peserta didik. Kedua, pengembangan setiap dimensi pengembangan diri tidak ditindaklanjuti di luar lingkungan sekolah. Ketiga, guru kesulitan dalam memotivasi siswa agar percaya diri dalam mengungkapkan sesuatu. Keempat, guru sulit untuk mengetahui tingkat pemahaman siswa terhadap materi pembelajaran. Kelima, guru kesulitan mengamati peserta didik dalam berinteraksi dengan lingkungan sosial dan alam. Keenam, guru belum maksimal dalam mengintegrasikan pendidikan karakter dalam semua mata pelajaran. Ketujuh, guru kesulitan memberikan tugas dalam ranah abstrak.

Guru menghadapi masalah dalam pencapaian standar penilaian, pertama, guru menghadapi masalah dalam menyusun instrumen penilaian baik tes maupun non-tes. Kedua, terutama dalam mengukur penilaian dari ranah sikap, guru kesulitan dalam 
melengkapi format penilaian terutama rekapitulasi nilai menjadi bentuk deskriptif. Ketiga, guru kesulitan melakukan penilaian proses karena jumlah siswa yang tidak sedikit. Keempat, guru belum memahami bagaimana melakukan penilaian autentik. Kelima, guru kesulitan dalam menyusun rubrik penilaian yang sesuai dengan kompetensi dasar. Keenam, guru kesulitan dalam mengolah hasil penilaian untuk mengetahui kemajuan belajar siswa serta untuk mengetahui permasalahan belajar siswa. Ketujuh, penilaian proses belum seutuhnya dipahami oleh guru sebagai contoh pelaksanaan analisis jarang masih dilaksanakan oleh guru.

Tujuan dari penelitian yang dilakukan dimaksudkan untuk mengkaji pelaksanaan Kurikulum 2013 di sekolah menengah pertama. Secara khusus penelitian mengenai dinamika pelaksanaan Kurikulum 2013 bertujuan untuk: mengetahui dinamika pelaksanaan kurikulum 2013 terhadap peningkatan pemahaman guru PPKn SMP di Kota Semarang; mengetahui tingkat pemahaman guru terhadap perencanaan, pelaksanaan, dan penilaian hasil belajar berdasarkan Kurikulum 2013 di tingkat Sekolah Menengah Pertama di kota Semarang.

Manfaat dari penelitian ini ialah memberikan gambaran mengenai sejauh mana pemahaman guru tentang pelaksanaan kurikulum 2013 khususnya perihal pelaksanaan pembelajaran PPKn yang menggunakan kurikulum 2013 sejak tahap persiapan pembelajaran, pelaksanaan pembelajaran, sampai dengan tahap evaluasi atau penilaian pembelajaran menggunakan penilaian autentik.

\section{METODE}

Jenis penelitian yang digunakan dalam penelitian ini jenis penelitian deskriptif. Penelitian dengan menggunakan metode deskriptif memberikan gambaran, merinci, dan menganalisis data pada permasalahan yang terjadi saat ini serta memusatkan pada pemecahan permasalahan aktual. Adapun pendekatan yang digunakan dalam penelitian ini menggunakan pendekatan kualitatif.

Penelitian dilaksanakan pada bulan September sampai dengan Oktober 2016, lokasi penelitian di Sekolah Menengah Pertama Negeri 2, Sekolah Menengah Pertama Negeri 5, Sekolah Menengah Pertama Negeri 11, Sekolah Menengah Pertama Negeri 21, yang keseluruhan sekolah tersebut berlokasi di Kota Semarang. Sasaran dari penelitian yakni sekolah-sekolah yang telah menerapkan kurikulum sejak Juli tahun 2013, dan yang menjadi subjek penelitian ialah guru-guru mata pelajaran Pendidikan Pancasila dan Kewarganegaraan (PPKn). Prosedur penelitian yang dilakukan dalam penelitian ini pada dasarnya sama dengan prosedur penelitian-penelitian kualitatif pada umumnya, yaitu melakukan identifikasi masalah, pembatasan masalah, penetapan fokus masalah, pelaksanaan penelitian, pengolahan dan pemaknaan data, pemunculan teori, dan pelaporan penelitian (Sudjana \& Ibrahim, 2001, p. 62).

Teknik pengumpulan data menggunakan angket (questionnaire), wawancara (interview), pengamatan (observation), dan dokumentasi (documentation). Setelah mengumpulkan data dengan informasi yang telah dibutuhkan melalui angket, wawancara, observasi, dan dokumentasi maka dapat diperoleh data primer maupun data sekunder yang selanjutnya diolah dan dilakukan analisis secara kualitatif. 


\section{HASIL PENELITIAN}

Implementasi kurikulum merupakan sebuah usaha yang diperlukan untuk memastikan pelaksanaan kurikulum di sekolah berjalan sebagaimana mestinya. Ukuran baik dalam pelaksanaan kurikulum dapat dilihat dari perbandingan antara kurikulum rencana dengan kurikulum aktual. Pelaksanaan dikatakan berjalan dengan baik jika perbedaan antara keduanya adalah sedikit. Bahkan, dalam kondisi istimewa dapat terjadi dalam pelaksanaan kurikulum aktual malah melebihi kurikulum yang telah direncanakan.

Dalam pelaksanaan kurikulum perlu dilakukan pelatihan dan pendampingan terhadap guru sebagai pihak yang akan menjalankan apa yang terdapat dalam kurikulum. Pelatihan dan pendampingan guru dilakukan untuk memastikan guru memahami kurikulum yang dilaksanakan di sekolah dalam bentuk pelaksanaan pembelajaran. Pemahaman kurikulum tidak cukup dengan memahami dokumen kurikulum, karena kurikulum harus mencakup empat elemen yang terkait satu sama lain yaitu kompetensi, materi, proses dan penilaian. Dokumen untuk keempatnya adalah terpisah sehingga mencari keterkaitan satu dengan yang lain, tentulah membutuhkan usaha yang luar biasa. Dengan demikian, pelatihan guru akan lebih efektif apabila tidak hanya menggunakan dokumen kurikulum , tetapi juga dengan menggunakan buku siswa dan guru.

Gambar Pemahaman Kurikulum Dalam Implementasi Kurikulum
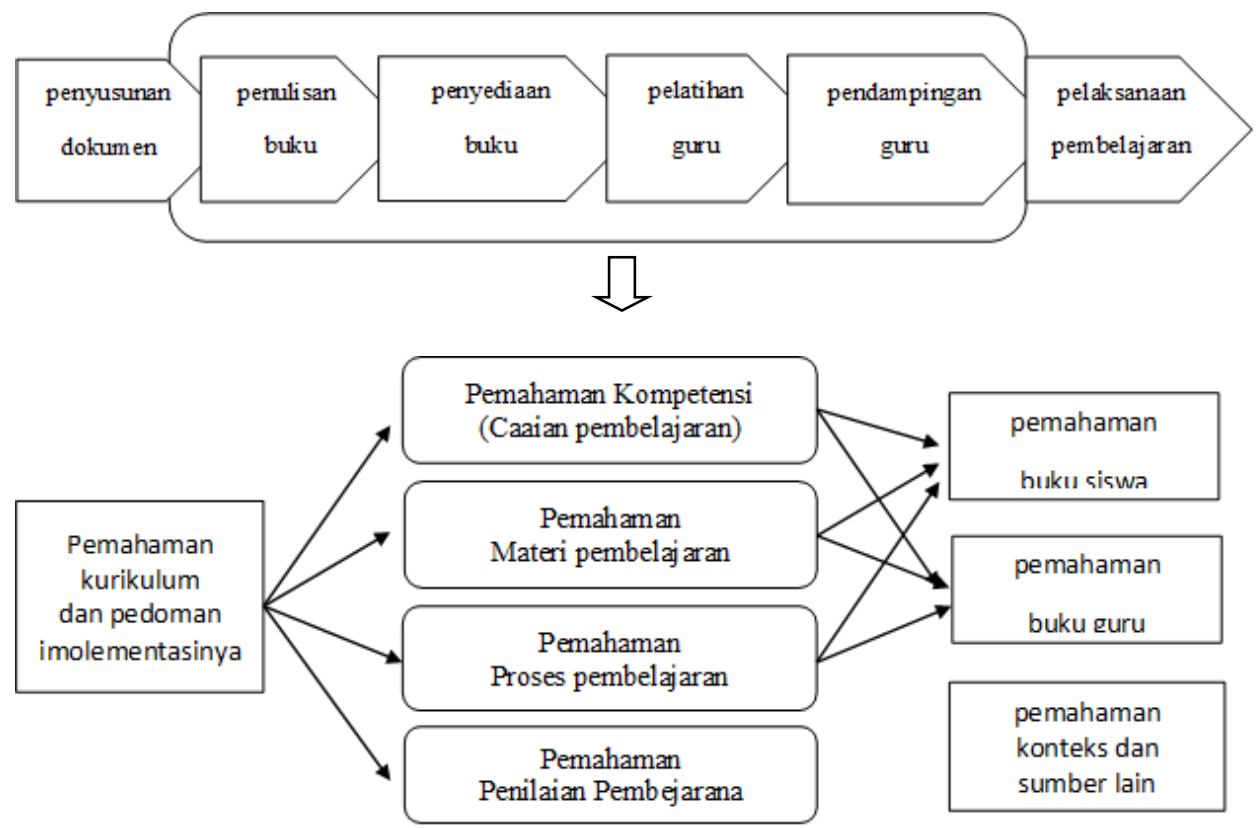

Berdasarkan hasil analisis data hasil penelitian mengenai "Dinamika Pelaksanaan Kurikulum 2013 Mata Pelajaran PPKn tingkat Sekolah Menengah Pertama di Kota Semarang" dapat disimpulkan hasilnya sebagai berikut.
Sumber: (Palupi, 2016)

1. Perencanaan Pembelajaran

PPKn

\section{Tingkat Sekolah Menengah Pertama}

Dalam penyusunan RPP, guru telah memahami langkah-langkah dalam menyusun RPP. Hal itu dapat dilihat dari penulisan identitas RPP, guru telah 
melakukannya dengan benar. Dalam menuliskan tujuan pembelajaran guru berpedoman pada KI 1, KI 2, KI 3, KI 4. Semua kompetensi inti untuk mata pelajaran PPKn harus disertakan, dan guru telah memahami hal itu dengan menyesuaikan tujuan pembelajaran dengan Kompetensi Inti. Dalam menyusun kegiatan pembelajaran, guru melakukannya mulai dari merumuskan kegiatan pembelajaran yang mencakup kegiatan pendahuluan, inti, dan penutup. Dalam pelaksanaan pembelajaran di RPP, guru telah melakukan dengan pembelajaran saintifik. Hal itu dapat dilihat penerapan prinsip 5M oleh guru yang merupakan ciri dari pendekatan saintifik. Dalam penyusunan materi yang akan diberikan guru kepada siswa, guru telah menyesuaikan materi pembelajaran yang terdapat pada silabus mata pelajaran PPKn yang telah disesuaikan dengan kompetensi inti, kompetensi dasar dan tujuan dari pembelajaran.

Dalam RPP, yang menjadi sumber belajar ialah buku guru dan buku siswa, di sekolah yang menjadi lokasi penelitian, siswa dan guru telah menggunakan buku guru dan buku siswa untuk melaksanakan pembelajaran. Metode yang digunakan ialah diskusi kelompok dengan guru memberikan sebuah permasalahan kepada masing-masing kelompok. Dalam pelaksanaan diskusi telah diterapkan prinsip 5M. Pada saat pelaksanaan diskusi kelompok, guru berperan sebagai fasilitator dan evaluator dimana guru melakukan penilaian sikap dan keterampilan siswa selama proses pembelajaran kelompok berlangsung.

Aspek penilaian yang disusun guru dalam RPP, guru melakukan penilaian pembelajaran menggunakan penilaian autentik dimana guru menilai aspek pengetahuan, aspek sikap, dan keterampilan siswa. Pada dasarnya, pelaksanaan pembelajaran ialah bagaimana cara mengajarkan materi pembelajaran kepada siswa agar tujuan pembelajaran tercapai (kompetensi) dan memastikan siswa bahwa capaian sesuai dengan target yang telah ditetapkan (penilaian). Oleh karenanya, untuk dapat melaksanakan pembelajaran dengan baik, dalam tahap persiapan sebelum pelaksanaan pembelajaran dilakukan, guru harus memahami kompetensi, materi, proses, dan penilaian pembelajaran.

\section{Pelaksanaan Pembelajaran Mata Pelajaran PPKn Tingkat Sekolah Menengah Pertama}

Dalam pelaksanaan pembelajaran Kurikulum 2013 mata pelajaran PPKn tingkat sekolah menengah pertama secara garis besar guru sudah melaksanakan proses pembelajaran sesuai RPP Kurikulum 2013 tahun ajaran 2016/2017 yang diterapkan dalam proses pembelajaran tahun ajaran 2016/2017 walaupun dalam prinsip pembuatan RPP harus menyesuaikan dengan karakteristik peserta didik namun pembelajaran bisa terlaksana dengan baik, dan sudah melalui proses pembelajaran dengan pendekatan saintifik. Walaupun guru mata pelajaran PPKn belum membuat RPP secara sempurna sesuai yang diharapkan kurikulum 2013, namun dalam pelaksanaan Pembelajaran mata pelajaran PPKn sudah berjalan dengan harapan, dan siswa mampu menerima dengan baik materi yang disampaikan guru.

Pada tahap pendahuluan, guru memulai dengan melakukan apersepsi, motivasi, dan penyampaian tujuan dimana dalam kegiatan tersebut guru melaksanakan tahapan mengaitkan materi pembelajaran sekarang dengan pengalaman peserta didik atau pembelajaran sebelumnya, mengajukan pertanyaan yang menantang, menyampaikan 
manfaat materi pembelajaran, dan/atau mendemonstrasikan sesuatu yang terkait dengan tema, melakukan pengecekan perilaku awal (entry behavior), dan menyampaikan tujuan/kompetensi yang akan dicapai peserta didik. Guru sudah menguasai materi pelajaran, hal itu dilihat dari penampilan guru PPKn yang mampu menyajikan materi konsep dengan benar, menyesuaikan materi dengan tujuan pembelajaran, mengaitkan materi dengan pengetahuan lain yang relevan, perkembangan iptek dan kehidupan nyata, menyajikan materi secara sistematis.

Dalam melaksanakan pembelajaran PPKn dengan pendekatan saintifik, aktivitas yang dilakukan guru dengan menerapkan strategi pembelajaran yang mendidik dengan melakukan aktivitas seperti memfasilitasi peserta didik untuk mengamati dan menemukan masalah yang ingin diketahui, guru memberi stimulus/memfasilitasi peserta didik untuk merumuskan pertanyaan, guru memfasilitasi peserta didik untuk mencoba/mengumpulkan data/informasi dan mengolah/menganalisis data/informasi untuk membuat kesimpulan, guru memfasilitasi peserta didik mengomunikasikan pengetahuan (kesimpulan) yang diperoleh. Pada saat pelaksanaan pembelajaran, guru telah melibatkan peserta didik dalam pembelajaran. Guru dalam fase ini menumbuhkan partisipasi aktif peserta didik (mental, fisik, dan sosial) melalui interaksi guru, peserta didik, sumber belajar, merespon positif partisipasi peserta didik, menunjukkan sikap terbuka terhadap respons peserta didik, dan guru mampu menumbuhkan keceriaan atau antusiasme peserta didik dalam belajar.

Pada saat kegiatan penutup, guru telah melakukan beberapa kegiatan antara lain dengan membuat rangkuman yang melibatkan peserta didik, melakukan refleksi terhadap kegiatan yang sudah dilaksanakan, memberikan umpan balik terhadap proses dan hasil pembelajaran, memberi tindak lanjut dengan memberikan arahan kegiatan berikutnya dan/atau tugas pengayaan dan/atau remedi.

Dalam proses pelaksanaan pembelajaran PPKn di kelas, guru sejak kegiatan apersepsi hingga kegiatan penutup telah menerapkan prinsip pembelajaran saintifik dengan melaksanakan

$5 \mathrm{M}$ (mengidentifikasi/mengamati, mencoba, menanya, menalar, mengomunikasikan). Mengidentifikasi/mengamati, mencoba, menanya, menalar, mengomunikasikan adalah urutan logis pengalaman-pengalaman belajar yang secara nyata tertulis di dalam Peraturan Menteri Pendidikan dan Kebudayaan (Permendikbud) Nomor 103 Tahun 2014 tentang Pembelajaran pada Pendidikan Dasar dan Menengah. Mengamati, menanya, mengumpulkan informasi, mengasosiasi, mengomunikasikan adalah tahapan-tahapan pembelajaran Kurikulum 2013 dengan pendekatan saintifik yang merupakan pembelajaran berpusat pada siswa.

Kurikulum 2013 menekankan pada dimensi pedagogik modern dalam pembelajaran, yaitu menggunakan pendekatan ilmiah. Pendekatan ilmiah (scientific approach) dalam pembelajaran semua mata pelajaran meliputi menggali informasi melaui pengamatan, bertanya, percobaan, kemudian mengolah data atau informasi, menyajikan data atau informasi, dilanjutkan dengan menganalisis, menalar, kemudian menyimpulkan, dan mencipta. Untuk mata pelajaran, materi, atau situasi tertentu, sangat mungkin pendekatan 
ilmiah ini tidak selalu tepat diaplikasikan secara prosedural. Pada kondisi seperti ini, tentu saja proses pembelajaran harus tetap menerapkan nilai-nilai atau sifat-sifat ilmiah dan menghindari nilai-nilai atau sifat-sifat non-ilmiah.

Proses pembelajaran harus menyentuh tiga ranah, yaitu sikap, pengetahuan, dan keterampilan. Dalam proses pembelajaran berbasis pendekatan ilmiah, ranah sikap menggamit transformasi substansi atau materi ajar agar peserta didik tahu tentang "mengapa". Ranah keterampilan menggamit transformasi substansi atau materi ajar agar peserta didik tahu tentang "bagaimana". Ranah pengetahuan menggamit transformasi substansi atau materi ajar agar peserta didik tahu tentang "apa". Hasil akhirnya adalah peningkatan dan keseimbangan antara kemampuan untuk menjadi manusia yang baik (soft skills) dan manusia yang memiliki kecakapan dan pengetahuan untuk hidup secara layak (hard skills) dari siswa yang meliputi aspek kompetensi pengetahuan, sikap, dan keterampilan. Pada akhir pembelajaran atau pada kegiatan penutup yang merupakan bagian akhir dari pelaksanaan pembelajaran menurut Kurikulum 2013, guru bersama siswa baik secara individual maupun kelompok harus melakukan refleksi agar dapat melakukan evaluasi terhadap semua rangkaian kegiatan belajar atau aktivitas pembelajaran beserta hasil-hasil yang diperoleh untuk selanjutnya secara bersama menemukan manfaat langsung maupun tidak langsung dari hasil pembelajaran yang telah berlangsung. Guru memberikan umpan balik terhadap proses dan hasil pembelajaran. Guru melakukan kegiatan tindak lanjut dalam bentuk pemberian tugas, baik tugas individual maupun kelompok. Kemudian guru memberikan informasi tentang rencana kegiatan pembelajaran untuk pertemuan berikutnya.

Jika dalam pelaksanaan pembelajaran mata pelajaran PPKn dilaksanakan menggunakan proses 5M, maka akan dapat mengantarkan siswa untuk menemukan pengetahuan yang ingin diajarkan. Pada dasarnya, hal itu merupakan model pembelajaran berbasis penemuan yang merupakan bentuk konkret dari proses 5M. Hal itu dikarenakan dalam pembelajaran kurikulum 2013 khususnya mata pelajaran PPKn akan membentuk tiga kompetensi secara komprehensif (kognitif, afektif, dan psikomotor). Guru hendaknya perlu memikirkan pembelajaran yang cukup kompleks sehingga menuntut siswa untuk melaksanakan pembelajaran secara berkelompok dalam waktu yang relatif lama. Model-model pembelajaran seperti problem based learning, atau model pembelajaran berbasis project merupakan bentuk ideal dari model pembelajaran yang akan dipakai. Dalam model pembelajaran seperti problem based learning dan project, proses $5 \mathrm{M}$ akan terlihat secara utuh. Jika guru menggunakan dua model pembelajaran tersebut, maka guru harus benar-benar memantau kinerja siswa sejak dari perencanaan sampai siswa menyajikan laporan hasil kerja mereka.

Membentuk kreativitas pada diri siswa, dapat dilakukan dengan melatih mereka agar menguasai keterampilan-keterampilan pembentukan kreativitas. Keterampilan pembentuk kreativitas yang menonjol pengaruhnya menurut hasil penelitian Dyers, dkk. Antara lain: keterampilan mengamati (observing), keterampilan menanya (questioning), keterampilan mencoba (experimenting), keterampilan berjejaring (networking), dan keterampilan mencari keterkaitan (associating). Melalui proses 
"5M", diharapkan akan memberikan pengalaman berkesan sekaligus kreatif dalam diri siswa. Proses ini dilakukan secara kolaboratif/bekerja sama dengan sesama siswa, dalam hal ini keterampilan bersosialisasi diwujudkan dalam bentuk dua keterampilan, yaitu keterampilan mengomunikasikan dan keterampilan bekerja sama, karena pada dasarnya jejaring terbentuk melalui komunikasi dan kolaborasi.

Setiap langkah dalam pembelajaran dengan pendekatan saintifik harus menggunakan kata kerja aktif. Hal itu mengandung arti bahwa setiap langkah tersebut harus dilaksanakan sendiri oleh siswa dengan arahan dan pengawasan guru. Dengan demikian, pembelajaran saintifik merupakan pembelajaran yang berbasis aktivitas siswa, sebagaimana pengertian dari pembelajaran berbasis aktivitas itu sendiri, siswa memperoleh pengalaman terhadap pengetahuan, keterampilan, dan bahkan sikap melalui aktivitas-aktivitas yang dilakukan, kompetensinya dibentuk dari mengerjakan aktivitas-aktivitas.

Metode saintifik sangat relevan dengan dua teori belajar, yaitu teori Bruner dan Piaget. Teori belajar Bruner disebut juga teori belajar penemuan. Ada empat hal pokok berkaitan dengan teori belajar Bruner. Pertama, individu hanya belajar dan mengembangkan pikirannya apabila ia menggunakan pikirannya. Kedua, dengan melakukan proses-proses kognitif dalam proses penemuan, siswa akan memperoleh sensasi dan kepuasan intelektual yang merupakan suatu penghargaan intrinsik. Ketiga, satu-satunya cara agar seseorang dapat mempelajari teknik-teknik dalam melakukan penemuan adalah dengan ia memiliki kesempatan untuk melakukan penemuan. Keempat, dengan melakukan penemuan maka akan memperkuat retensi ingatan pad diri siswa. Empat hal di atas adalah bersesuaian dengan proses kognitif yang diperlukan dalam pembelajaran menggunakan metode saintifik.

Teori Piaget, menyatakan bahwa belajar berkaitan dengan pembentukan dan perkembangan skema (jamak skemata). Skema merupakan suatu struktur mental atau struktur kognitif yang dengannya seseorang secara intelektual beradaptasi dan mengkoordinasi lingkungan sekitarnya (Baldwin, 1967). Skema tidak pernah berhenti berubah, skemata seorang anak akan berkembang menjadi skemata orang dewasa. Proses yang menyebabkan terjadinya perubahan skema disebut dengan adaptasi. Proses terbentuknya adaptasi ini dapat dilakukan melalui dua cara yaitu asimilasi dan akomodasi. Asimilasi merupakan proses kognitif yang dengannya seseorang mengintegrasikan stimulus yang dapat berupa persepsi, konsep, hukum, prinsip ataupun pengalaman baru ke dalam skema yang sudah ada di dalam pikirannya. Akomodasi dapat berupa pembentukan skema baru yang dapat cocok dengan ciri-ciri rangsangan yang ada atau memodifikasi skema yang telah ada sehingga cocok dengan ciri-ciri stimulus yang ada. Dalam pembelajaran diperlukan adanya penyeimbangan atau ekuilibrium antara asimilasi dengan akomodasi.

Hal seperti demikian pun terjadi di sekolah menengah pertama yang menjadi tempat penelitian, dimana pembelajaran PPKn di kelas guru menerapkan prinsip 5M dalam pembelajaran. Siswa lebih mendominasi keaktifan di kelas. Guru hanya mengarahkan siswa untuk lebih aktif dengan menerapkan $5 \mathrm{M}$. 


\section{Evaluasi Hasil Belajar Mata Pelajaran PPKn Tingkat Sekolah Menengah Pertama}

Selain kemampuan menyampaikan materi pembelajaran, guru juga harus bisa mengevaluasi keberhasilan kegiatan pembelajaran yang telah dilakukan dengan cara mengetahui hasil belajar siswa. Dari hasil penelitian, dapat diketahui bahwa guru Pendidikan Pancasila dan Kewarganegaraan di SMP Negeri yang menjadi subjek penelitian memiliki persepsi yang positif terhadap penilaian autentik. Dengan persepsi yang termasuk dalam kategori positif. Hal itu mengindikasikan guru-guru tersebut memiliki kecenderungan untuk melakukan penilaian autentik dalam pembelajaran PPKn di kelas. Meskipun demikian, melalui wawancara yang dilakukan terhadap beberapa guru, istilah penilaian autentik belum terlalu familiar bagi sebagian guru. Guru-guru lebih familiar dengan istilah penilaian kinerja atau penilaian alternatif.

Untuk melakukan evaluasi pembelajaran pada aspek pengetahuan, guru melakukannya dengan mengembangkan instrumen penilaian pengetahuan (tes), melaksanakan penilaian pengetahuan selama proses pembelajaran (tes lisan/tertulis dan penugasan), mendokumentasikan hasil penilaian pengetahuan, serta dengan menindaklanjuti hasil penilaian pengetahuan oleh guru (laporan dan tindak lanjut lainnya, misalnya remedial atau pengayaan). Pada evaluasi pembelajaran untuk aspek sikap, yang dilakukan oleh guru ialah dengan mengembangkan instrumen penilaian sikap oleh guru (lembar observasi sikap), melaksanakan penilaian sikap selama proses pembelajaran dengan teknik observasi dan jurnal, mendokumentasikan hasil penilaian kompetensi sikap, dan menindaklanjuti hasil penilaian sikap oleh guru (laporan dan tindak lanjut lainnya, misalnya penguatan atau perbaikan sikap). Aspek keterampilan, dalam melakukan evaluasi pembelajaran guru melakukan kegiatan dengan mengembangkan instrumen penilaian keterampilan (rubrik untuk: tes kinerja, proyek, portofolio), melaksanakan penilaian keterampilan yang relevan selama proses pembelajaran atau situasi tes kinerja, mendokumentasikan hasil penilaian keterampilan, menindaklanjuti hasil penilaian keterampilan oleh guru (laporan dan tindak lanjut lainnya, misalnya remidial atau pengayaan).

Selain penilaian yang dilakukan oleh guru, penilaian pembelajaran juga dilakukan oleh sesama siswa. Pada saat penilaian dilakukan oleh siswa, maka kegiatan yang dilakukan oleh guru ialah melakukan pendampingan dan memfasilitasi siswa dalam hal melakukan pengembangan instrumen penilaian diri dan penilaian teman sebagai bagian dari penilaian sikap, memfasilitasi pelaksanaan penilaian diri dan penilaian teman selama proses pembelajaran atau pada kesempatan khusus, mendokumentasikan hasil penilaian diri dan penilaian teman, serta dengan menindaklanjuti hasil penilaian sikap oleh guru (laporan dan tindak lanjut lainnya, misalnya penguatan atau perbaikan sikap).

Dalam pasal 8 Peraturan Menteri pendidikan dan Kebudayaan Nomor 53 Tahun 2015 tentang Penilaian Hasil Belajar oleh pendidik dan satuan pendidikan, dijelaskan bahwa penilaian hasil belajar oleh pendidik dilakukan untuk memantau proses, kemajuan belajar, dan perbaikan hasil belajar melalui penugasan dan pengukuran pencapaian satu atau lebih kompetensi dasar. Penilaian yang dilakukan meliputi aspek sikap, dilakukan melalui observasi/pengamatan sebagai sumber 
informasi utama dan pelaporan menjadi tanggungjawab wali kelas atau guru kelas, hasil penilaian pencapaian sikap oleh pendidik disampaikan dalam bentuk predikat atau deskripsi; penilaian aspek pengetahuan dilakukan melalui tes tertulis, tes lisan, dan penugasan sesuai dengan kompetensi yang dinilai; penilaian keterampilan dilakukan melalui praktik, produk, proyek, portofolio, dan/atau teknik lain sesuai dengan kompetensi yang dinilai. Hasil penilaian pencapaian pengetahuan dan keterampilan oleh pendidik disampaikan dalam bentuk angka dan/atau deskripsi, dan peserta didik yang belum mencapai KKM harus mengikuti pembelajaran remedi. Dari hasil penelitian didapat bahwa guru mata pelajaran PPKn di sekolah yang diteliti telah menerapkannya.

Proses penilaian dalam pembelajaran merupakan kegiatan yang hasilnya tertulis, nyata, mudah dipahami, dan dapat dilihat oleh banyak pihak. Selain itu, penilaian pembelajaran merupakan salah satu bentuk pertanggungjawaban guru terhadap pelaksanaan pembelajaran yang dilakukan selama satu periode pembelajaran (Palupi, 2016). Dalam melakukan penilaian, guru hendaknya memperhatikan beberapa hal seperti kesahihan, keobjektifan, keadilan kepada semua siswa, dan dilaksanakan dengan penuh kehati-hatian.

Penilaian pada pembelajaran dengan pendekatan saintifik meliputi penilaian proses, penilaian produk, dan penilaian sikap. Penilaian proses atau keterampilan, dilakukan melalui observasi saat siswa bekerja kelompok, bekerja individu, berdiskusi, maupun saat presentasi dengan menggunakan lembar observasi kinerja. Penilaian produk berupa pemahaman konsep, prinsip, dan hukum dilakukan dengan tes tertulis.
Penilaian sikap, melalui observasi saat siswa bekerja kelompok, bekerja individu, berdiskusi, mau pun saat presentasi dengan menggunakan lembar observasi sikap. Penilaian autentik dalam kurikulum 2013 ialah penilaian yang dilakukan oleh guru terhadap siswa tanpa siswa merasa bahwa dia sedang dinilai. Ketika siswa sedang beraktivitas melaksanakan $5 \mathrm{M}$ saat itulah guru mulai mengamati siswa untuk melakukan penilaian. Penilaian ini dilakukan terhadap kemampuan yang bermanfaat bagi siswa dikemudian hari. Penilaian autentik ini dilakukan secara terus menerus pada saat siswa sedang mengerjakan tugas, diskusi, membuat laporan di kelas, melakukan percobaan, paparan, dan sebagainya.

\section{SIMPULAN}

Guru mata pelajaran PPKn di Sekolah Menengah Pertama di Kota Semarang telah memahami pelaksanaan Kurikulum 2013. Hal itu dapat dilihat dari bagaimana mereka mempersiapkan pembelajaran PPKn dengan menggunakan prinsip-prinsip dalam Kurikulum 2013, mulai dari perencanaan sampai dengan evaluasi atau penilaian pembelajaran PPKn.

Dalam pelaksanaan pembelajaran, guru telah memahami bagaimana seharusnya pelaksanaan pembelajaran menggunakan kurikulum 2013 yang dikenal dengan menggunakan langkah 5M, yaitu mengamati, menanya, mencoba, menalar, dan mengomunikasikan, serta dengan menggunakan penilaian autentik.

Dalam pelaksanaan evaluasi atau penilaian, guru telah memahami dan mampu menggunakan penilaian autentik dalam mengevaluasi hasil belajar siswa. Dalam penilaian autentik ini, guru melaksanakan penilaian terhadap tiga aspek yakni penilaian 
aspek pengetahuan, penilaian aspek sikap, dan penilaian keterampilan yang menjadi penilaian utama hasil belajar siswa ada mata pelajaran PPKn.

\section{UCAPAN TERIMA KASIH}

Terima kasih disampaikan kepada Pimpinan Fakultas Ilmu Sosial Universitas Negeri Semarang yang telah memberikan dukungan kepada peneliti untuk melaksanakan penelitian. Terima kasih juga kami ucapkan kepada pimpinan dan seluruh dosen di Jurusan Politik dan Kewarganegaraan Universitas Negeri
Semarang yang telah memberikan dukungan kepada penulis untuk menyelesaikan penelitian.

\section{DAFTAR PUSTAKA}

Baldwin, A. L. (1967). Theories of child development.

Palupi, D. T. (2016). Cara mudah memahami kurikulum. Surabaya: Jaring Pena.

Peraturan Menteri Pendidikan dan Kebudayaan Nomor 103 Tahun 2014 tentang Pembelajaran Pada Pendidikan Dasar Dan Pendidikan Menengah

Sudjana, N., \& Ibrahim, R. (2001). Penelitian dan penilaian pendidikan. Bandung: Sinar Baru. 